\title{
Estimating the Equilibrium Real Exchange Rate in Algeria during the period: 1980-2015
}

\author{
Samir AIT YAHIA ${ }^{1}$, Tarek DJEDDI ${ }^{2, *}$, Tayeb LOUAFI ${ }^{1}$ \\ ${ }^{1}$ Larbi Tebessi University, Tebessa, Algeria \\ ${ }^{2}$ ENSSEA ex. INPS, Kolea, Algeria \\ *Corresponding author: tarek.djeddi@gmail.com
}

\begin{abstract}
The aim of this paper is to estimate the long-run Equilibrium Real Exchange Rate (ERER) path using VECM approach, and assesses the degree of misalignment in Algeria. Based on annual data from 1980 to 2015, our results show that the macroeconomic variables such as terms of trade, trade openness, differential productivity with trading partners (Balassa-Samuelson effect), real price of oil, and government expenditures, plays significant role in determining the equilibrium of Algeria's ERER, the results also reveal that Algerian economy suffered from RER misalignment. As finding, and according to the Edwards' [6] Model and the Cashin's [2] model, results showed same evidences that there are three episodes of undervaluation of the Algerian dinar's and also three episodes of overvaluation, the seventh episode (2004-2015) shows that the Actual ERER appears to have been close to its estimated equilibrium.
\end{abstract}

Keywords: equilibrium real exchange rate, misalignment, error correction mechanism, dinar, Algeria

Cite This Article: Samir AIT YAHIA, Tarek DJEDDI, and Tayeb LOUAFI, "Estimating the Equilibrium Real Exchange Rate in Algeria during the Period: 1980-2015." Journal of Finance and Economics, vol. 5, no. 5 (2017): 211-218. doi: 10.12691/jfe-5-5-3.

\section{Introduction}

The Real Exchange Rate (RER)* has been defined in a number of alternative ways in the economic literature. According to some views: the real exchange rate was defined as the nominal exchange rate corrected by the ratio of the foreign to the domestic price level, more authors have defined the real exchange rate in the context of a dependent economy type model with tradable and non-tradable goods. In this setting the real exchange rate has been defined as the (domestic) relative price of tradable and non-tradable goods. So, the equilibrium real exchange rate (ERER) is defined as that relative price of tradable to non-tradable that, for given sustainable (equilibrium) values of other relevant variables such as taxes, international prices and technology, results in the simultaneous attainment of internal and external equilibrium.

Once this equilibrium level is established, it is possible to determine, among other things, whether the actual real exchange rate is misaligned (overvalued or undervalued). RER misalignment has been considered as the main cause of economic instability and the dismal economic performance of numerous countries. In the literature, an exchange rate is described as overvalued or undervalued when it appreciates over or depreciates under its equilibrium level.

Like other developing countries that aim to enhance their external balance and achieve economic stability,

\footnotetext{
* In this paper, we use the real effective exchange rate REER.
}

Algeria has adopted a number of different exchange rate regimes in the last six decades. From 1974, the exchange rate of Algerian Dinar was pegged to a basket of currency, in which the U.S. dollar was assigned a relatively large weight due to its importance in hydrocarbon export receipts and debt-service payments. After the oil shock in 1986, the Bank of Algeria let the Algerian dinar depreciate against the basket. In 1994, one of the immediate objectives of the adjustment program was to correct the previous real appreciation of the Algerian dinar. Since 1995, Algeria's exchange rate policy has aimed at maintaining a stable real exchange rate, and the managed float regime was implemented from 1996 until today. Through its intervention, the Bank of Algeria adjusts periodically the nominal exchange rate so as to achieve its real exchange rate target.

In order to estimate the DZD's real exchange rate misalignment, we follow first, the Edwards' $(1987,1989)$ model $[6,8]$ to Algeria where the ERER is itself a function of a number of variables (Fundamentals) including import tariff (terms of trade), the relative productivity (BalassaSamuelson Effect) [1,18], Government consumption and the degree of openness, by using co-integration of Johanson and the Error Correction Model for the adjustment between the short and long run [11].

A study by Cashin, and Sahay [2], developed a long-run equilibrium exchange rate model for commodity-exporting countries found that: in many commodity-dependent lowincome countries, real commodity export prices and real exchange rates move together in the long run. So, this paper tries in second place, to apply the Cashin et al. (2002) model to Algeria [2]. 


\section{Literature Review}

For developing countries as Algeria, because primary commodities dominate their exports, fluctuation in world commodity prices have the potential to explain a large share of movements in their terms of trade. However, while terms of trade fluctuations have been considered a key determinant of developing country real exchange rates $[8,9]$.

It is worth highlighting that the real exchange rate misalignment is the state in which the actual real exchange rate deviates from the equilibrium level. In this respect, various methods have been explored by the relevant theoretical and empirical studies for the purpose of determining the real exchange rate equilibrium.

The most widely used approach to measure real exchange rate misalignment is the Purchasing Power Parity (PPP) method's developed by Cassel, due to its simplicity. It relies on the Law of One Price (LOP) and built upon a perfect market arbitrage. The concept of PPP is often the first port of call for economists and market analysts who wish to estimate the equilibrium real exchange rate. The most widely used methodology to confirm or reject PPP is based on the analysis of the time series characteristics of the REER, which is assumed to measure changes in price level difference between a country and its trading partners. If the REER series is stationary and the speed of convergence of the REER towards its mean is fast enough, then PPP can be considered to hold.

Attempts by economists to model long- run movements in real exchange rates have typically proven to be rather unsuccessful. Meese and Rogoff [16] demonstrated that a variety of linear structural exchange rate models failed to forecast more accurately than a naïve random walk model for both real and nominal exchange rates. This result is contrary to the theory of PPP. Accordingly, PPP has proven to be a weak model of the long-run real exchange rate (Paul Cashin et al, 2002) [2], and recent work has emphasized the time varying nature of the long-run real exchange rate.

However, among the different empirical approaches, three methodologies are most common: (1) the "Fundamental Equilibrium Exchange Rate (FEER)", as in Williamson (1994) [20]; (2) the "Behavioural Equilibrium Exchange Rate (BEER)" approach developed by Clark and MacDonald [4]; and (3) the "Natural Rate of Exchange (NATREX) » approach, as in Stein [19] .

The FEER approach defines the equilibrium exchange rate as the real exchange rate that meets simultaneously conditions of internal and external balances ${ }^{*}$. Thus, the FEER is the real exchange rate that is expected to generate a current account balance equal to the underlying capital flow over the cycle, given that the country is pursuing internal balance.

The BEER approach - in a similar fashion than Williamson's (1994) fundamental equilibrium exchange rate (FEER) approach [9], explains the real exchange rate behaviour in terms of economic fundamentals using

\footnotetext{
*Internal balance means that the economy operates at the full-capacity output, while the external balance refers to the current account sustainability.
}

reduced-form econometric equations. The BEER calculates the rate that is determined during the long run relationship between the exchange rate and its determinants: interest rate differential, terms of trade, differential productivity, net foreign assets and government debt.

The NATREX approach is also based on concepts of internal and external balances. In contrast to FEER approach it also analyzes determinants of the long-run real exchange rate equilibrium. In its reduced form it resembles the BEER approach.

\section{Empirical Framework}

To estimate the DZD's real effective exchange rate misalignment and find out the macroeconomic fundamentals which determine it, we use two different models, the Edwards' (1987) model [6], and the Cashin's (2002) model [2].

\subsection{The Edwards' (1987) Model}

Edwards Formulated an inter-temporal general equilibrium model for a small economy [6], where optimizing producers and consumers produce and consume three goods: importable, exportable and non-tradable. This framework enables us to analyze the relative transmission mechanisms between the real exchange rate and its fundamentals. The equilibrium RER is achieved by guaranteeing the simultaneous equilibrium of the internal and external sectors.

Edwards extends the inter-temporal general equilibrium model to a small open economy with optimizing consumers and producers [6,9], and analyses the relationship between terms of trade shocks and current account. He emphasizes the role of non-traded goods in the transmission process and how the terms of trade disturbances influence the current account. He shows that it is possible for a temporary import tariff to worsen the current account in the period when it is imposed.

Edwards also analyses equilibrium exchange rate behaviour and RER overvaluation by asking how the equilibrium real exchange rate reacts to changes in degree of restrictions to intra- and inter-temporal trade and the effects of a change in the degree of capital controls $[7,8]$, he finds first, that tariff liberalization does not necessarily result in an equilibrium real depreciation but depends on key parameters, second, that the substitution effect dominates the income effect under more restrictive conditions, and third, that expected future tariff hikes generate an equilibrium real appreciation in the current period.

It is worth to highlight that according to Edwards, the real and nominal variables exercise a noticeable influence the equilibrium of real exchange rate, where is the long-run, exclusively depends on the fundamentals. Edwards initiates his empirical analysis with the relative importance of real and nominal variables to explain the real exchange rate movement. The dynamic nature of the short-run of real exchange rate is represented by following equation [12]:

$$
\begin{aligned}
& \Delta \log e_{t}=\theta\left\{\log e_{t}^{*}-\log e_{t-1}\right\}+\lambda Z_{t} \\
& +\phi\left\{\log E_{t}-\log E_{t-1}\right\}
\end{aligned}
$$


Where $\Delta$ is the first difference, $e_{t}$ is the observed RER, $e_{t}^{*}$ is the equilibrium of RER which is the function of fundamentals, $Z_{t}$ is an index of macroeconomics policies (which are expressed by the growth rate of domestic credit and the fiscal deficit level), $E_{t}$ is the nominal exchange rate, $\log E_{t}-\log E_{t-1}$ is the nominal devaluation of local currency, $\theta, \lambda$ and $\phi$ are positive parameters that capture the adjustment process dynamic aspect.

It is also importantto note that in the long-run, the RER equilibrium is determined by the major relevant fundamentals (FUND). In this way, the relevant equation looks as follows:

$$
\log e_{t}^{*}=\beta_{0}+\beta(F U N D)_{t}
$$

Where $\left(e_{t}^{*}\right)$ is the equilibrium RER and (FUND) is a vector of the fundamental variables $(\mathrm{i}=1,2, \ldots \ldots, \mathrm{m})$.

\subsubsection{Data Source and Variables Definition}

We define the equilibrium real exchange rate in our model as follows:

$$
\begin{aligned}
\text { LREER }= & \alpha_{0}+\alpha_{1} L B S E+\alpha_{2} L O P E N+\alpha_{3} L T O T \\
& +\alpha_{4} L G O V+v .
\end{aligned}
$$

Following Edwards [6,8], the economic fundamentals, in our model, which determine the equilibrium RER behaviour are:

- LREER = the real effective exchange rate is defined as:

$$
R E E R=\prod_{i=1}^{n}\left\{N_{i / d z} \frac{P_{i}}{P_{d z}}\right\}^{\omega i}
$$

Where, $\mathrm{i}=1,2, \ldots \mathrm{n}$ is the number of trading partners of Algeria, $\prod_{i=1}^{n}$ is the geometric average, $N_{i / d z}$ is the nominal bilateral exchange rate of DZD and trade partner's currency. $P_{i}$ and $P_{d z}$ are respectively the consumer price index for the country $i$, and the consumer price index for Algeria, $\omega$ i is the trade weight for each Algeria's trading partner, and $\sum_{i=1}^{n} \omega_{i}=1$.

In our model, we use the REER of World Bank data $(2010=100)$ in logarithmic terms, and in certain form ${ }^{*}$.

- $L B S E=$ Real GDP per capita relative to trading partners: this variable is used as a proxy for the productivity differentials (Balassa-Samuelson Effect). The technological progress can be presented in two forms [1,18]:

(A) Product augmenting or income augmenting: results in an increase in real incomes and prices of non-tradable goods, then an appreciation of the real exchange rate.

(B) Factor augmenting: an increase in production with the same capacity in the economy results in a reduction in the price of non-tradable goods and the depreciation takes place.

\footnotetext{
*When the real exchange rate, in certain form, is over its equilibrium value, it means an overvaluation of the REER. An increase in the REER is equivalent to a real appreciation.
}

- $L T O T=$ real Terms Of Trade, is prices of exports divided by prices of imports, in logarithmic terms. IFS (IMF) 2017. Theoretically, the influence of terms of trade on the REER cannot be signed a priori, as this depends on whether income or substitution effects dominate $[8,9]$.

(A) The income effect: a positive shock on the terms of trade improves the trade balance and results in a higher demand for importable and non-tradable goods. Thus, the price of non-tradable production will increase and an appreciation of the real exchange rate will take place.

(B) The substitution effect: a positive shock of terms of trade or a decrease on import tariffs lets the price of importable goods lower than non-tradable goods, non-tradable production decrease and the real exchange rate depreciates.

$$
\text { TOT }=\text { Export prices } / \text { Import prices. }
$$

- $L O P E N=$ The degree of openness is a ratio of trade to gross domestic product GDP, which measures the degree of the country's trade openness we use the variable OPEN (total trade as percentage of GDP), in logarithmic terms. IFS (IMF) 2017. The impact of the degree of openness on REER cannot be signed a priori because degree of openness is theoretically ambiguous.

$$
\text { OPEN }=(\text { exports }+ \text { imports }) / \text { GDP. }
$$

- $L G O V=$ general government final consumption expenditure divided by GDP, in logarithmic terms from IFS (IMF) 2017, where the share of government spending on non-tradable goods is relative higher than that of private spending should experience equilibrium REER appreciation to follow an increase in the size of government. If government is spending more heavy on tradable goods, as for instance, in the case of military expenses, then the opposite is true: more government spending would produce REER depreciation.

$$
\text { GOV = Government expenditure / GDP. }
$$

\subsubsection{Unit Root Tests}

The dataset consists of annual data from 1980 to 2015. The ADF [5] and Phillips-Perron tests [17] indicate that the hypothesis of non-stationary cannot be rejected in level for all variables. However, for the first difference of the same variables the Phillips-Perron test indicate that the hypothesis of non-stationary is rejected at 1 percent confidence level, suggesting that these variables ( REER, BSE, TOT, OPEN, GOV) are integrated of order one I(1) as referred in Table 1.

\subsubsection{Cointegration Tests}

Engel-Granger [11] and Johansen (1995) tests confirms the existence of one cointegration relationship between the REER, TOT, OPEN, GOV and Algeria's productivity differential relative to its trading partners (Balassa-Samuelson Effect) $[1,18]$ at the $5 \%$ confidence level, as referred in Table 2 and Table 3.

\subsubsection{Finding and Discussion}

The estimated long-run real exchange rate equilibrium equation takes the following form: 


$\begin{array}{llll}(0.20638) & (0.53000) & (0.56635) & (0.82213) \\ {[-5.83099]} & {[4.03171]} & {[-6.86951]} & {[-1.82621]}\end{array}$

Table 1. ADF and PP Unit Root Tests

\begin{tabular}{|c|c|c|c|c|c|}
\hline \multirow{2}{*}{\multicolumn{2}{|c|}{ Variables }} & \multicolumn{2}{|c|}{ Level } & \multicolumn{2}{c|}{ First Difference } \\
\cline { 3 - 6 } & & t-ADF & t-PP & t-ADF & t-PP \\
\hline \multirow{2}{*}{ LREER } & \multirow{2}{*}{ Intercept Trend and Intercept } & -1.422824 & -1.050156 & $-4.337642^{* * *}$ & $-4.337642^{* * *}$ \\
\cline { 3 - 6 } & & -1.109913 & -1.411798 & $-4.258721^{* *}$ & $-4.287875^{* * *}$ \\
\hline \multirow{2}{*}{ LBSE } & \multirow{2}{*}{ Intercept Trend and Intercept } & $-2.713712^{*}$ & -1.641021 & -1.452776 & $-4.416052^{* * *}$ \\
\cline { 3 - 6 } & \multirow{2}{*}{ LTOT } & -0.884321 & -1.090010 & -1.620210 & $-4.565153^{* * *}$ \\
\hline \multirow{2}{*}{ LOPEN } & Intercept Trend and Intercept & -2.227488 & -2.169011 & $-5.150562^{* * *}$ & $-6.659348^{* * *}$ \\
\cline { 3 - 6 } & \multirow{2}{*}{ Intercept Trend and Intercept } & -2.075730 & -2.022564 & $-5.188836^{* * *}$ & $-7.836822^{* * *}$ \\
\hline \multirow{2}{*}{ LGOV } & \multirow{2}{*}{ Intercept Trend and Intercept } & -1.569951 & -1.796981 & $-4.023611^{* * *}$ & $-3.787287^{* * *}$ \\
\cline { 3 - 6 } & & -2.496108 & -2.449226 & $-3.380228^{*}$ & $-3.753978^{* *}$ \\
\cline { 3 - 6 } & & -2.251156 & -1.7741303 & $-4.253366^{* * *}$ & $-4.067228^{* * *}$ \\
\hline
\end{tabular}

NB: Variables are as defined in the text. ${ }^{* * *}$ and $* * *$ denote rejection at $10 \%, 5 \%$ and $1 \%$ critical values.

Table 2. Trace test for cointegration rank

\begin{tabular}{|c|c|c|c|c|}
\hline & Eigenvalue & Trace Statistic & $\begin{array}{c}0.05 \\
\text { Critical Value }\end{array}$ & Prob.** \\
\hline None ${ }^{*}$ & 0.721849 & 87.36920 & 69.81889 & 0.0011 \\
\hline At most 1 & 0.507197 & 43.86306 & 47.85613 & 0.1129 \\
\hline At most 2 & 0.320086 & 19.80312 & 29.79707 & 0.4363 \\
\hline At most 3 & 0.155868 & 6.686300 & 15.49471 & 0.6144 \\
\hline At most 4 & 0.026842 & 0.925106 & 3.841466 & 0.3361 \\
\hline
\end{tabular}

Trace test indicates 1 cointegrating eqn(s) at the 0.05 level

* denotes rejection of the hypothesis at the 0.05 level

**MacKinnon-Haug-Michelis (1999) p-values.

Table 3. Maximum Eigenvalue test for cointegration rank

\begin{tabular}{|c|c|c|c|c|}
\hline & Eigenvalue & Max-Eigen Statistic & $\begin{array}{c}0.05 \\
\text { Critical Value }\end{array}$ & Prob.** \\
\hline None $^{*}$ & 0.721849 & 43.50614 & 33.87687 & 0.0026 \\
\hline At most 1 & 0.507197 & 24.05994 & 27.58434 & 0.1326 \\
\hline At most 2 & 0.320086 & 13.11682 & 21.13162 & 0.4416 \\
\hline At most 3 & 0.155868 & 5.761194 & 14.26460 & 0.6440 \\
\hline At most 4 & 0.026842 & 0.925106 & 3.841466 & 0.3361 \\
\hline
\end{tabular}

Max-eigenvalue test indicates 1 cointegrating eqn(s) at the 0.05 level

* denotes rejection of the hypothesis at the 0.05 level

**MacKinnon-Haug-Michelis (1999) p-values.

Results are consistent with theoretical background:

- An increase in openness of 1 percent is associated with an appreciation of the REER of about 2.13 percent.

- An increase in BSE (real GDP per capita relative to trading partner countries) of 1 percent is associated with a depreciation of the REER of about 1.20 percent. It is « Factor augmenting » that dominates.

- An improvements on terms of trade of 1 percent is associated with a depreciation of the REER of about 3.9 percent (This means that the substitution effect is more important than the income effect).
- An increase of 1 percent of government consumption is associated with a depreciation of the REER of about 1.5 percent, relatively small depreciation due to an important government expenditure is mainly directed towards imported goods.

The misalignment between the actual real exchange rate (RER) and the long run real equilibrium exchange rate (ERER) can be calculated from the following formula:

$$
\text { Misalignment }=[(\mathrm{RER}-\mathrm{ERER}) / \mathrm{ERER}] * 100
$$

Where ERER is equilibrium real exchange rate and RER is actual real exchange rate. 


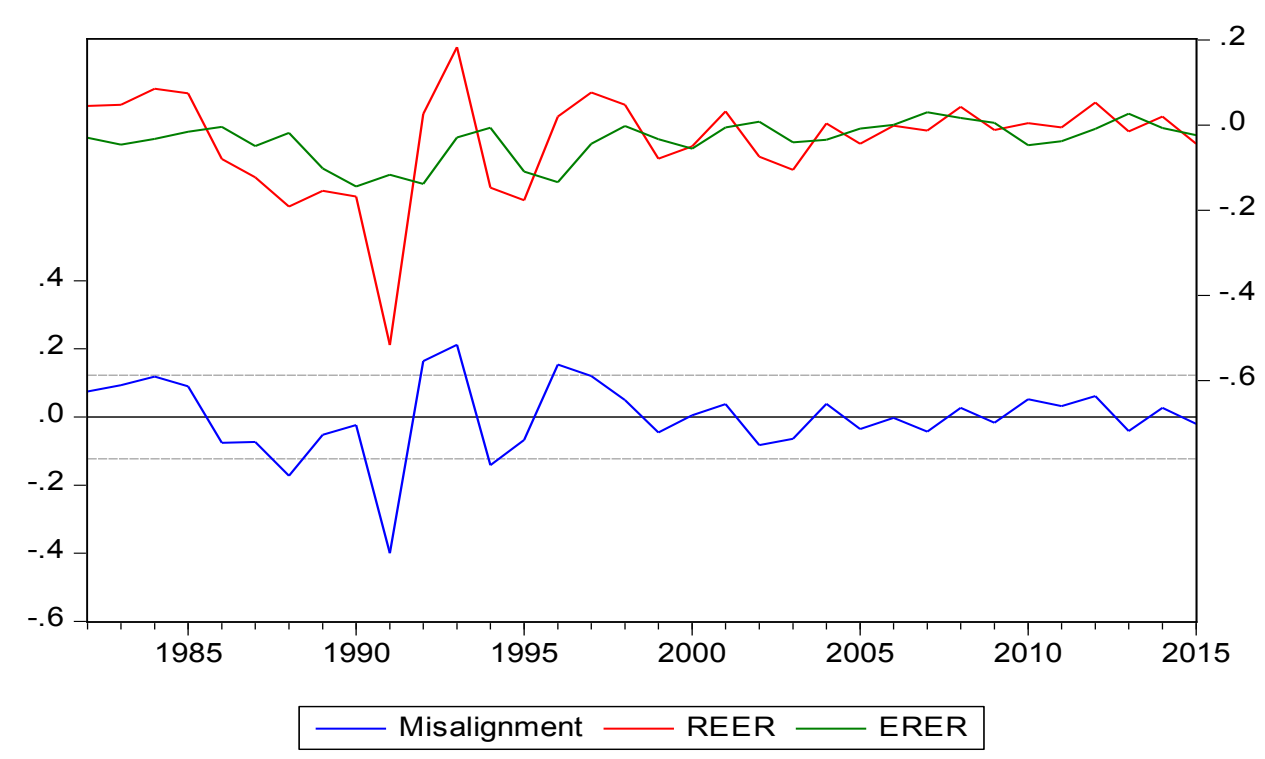

Figure 1. Actual RER, Equilibrium RER and Degree of Misalignment

As illustrated in Figure 1, the more misalignment increases, more the distance between equilibrium real exchange rate and actual real exchange rate increases.

Figure 1 shows three under-valuate episodes of DZD: (1986-1991, 1994-1995 and 2002-2003), and three episodes of DZD's overvaluation (1982-1985, 1992-1993 and 1996-2001 except 1999). The Actual REER appears to be close to its estimated equilibrium since 2004 until 2015. Figure 1 also shows the depreciation in response to the reverse oil shock during 1986-1991. Algeria experienced a short undervaluation in mid-1980s followed by a large devaluation in 1991 at $40 \%$, results showed a very large variation of Algerian misalignment between $1991(-40 \%)$ and $1993(+21 \%)$. In other side, the RER of Algeria was overvalued from the mid-1990s until 2001 (except 1999), following the increasing inflation rate and current account deficits.

In General, periods of major exchange rate misalignment in Algeria are associated with country's changes in inflation. Specifically, for the case of Algeria, episodes of overvaluation are associated with Algeria's episodes of high inflation. Similarly, episodes of undervaluation correspond to periods of decreasing inflation, during 2001-2008, the inflation rate reached its lowest level.

However, the correction made by the authorities in the second half of 2003 (by appreciating the nominal exchange rate) brought the REER back close to its equilibrium level. In 2006, the real exchange rate was relatively at its equilibrium value. It's important to note that Algeria's equilibrium exchange rate's was not affected by the latest global economic crises, in part due to prudent monetary policy.

For Algeria, the low misalignment in recent years can be explained by the abandonment of the real exchange rate targeting and gradual introduction of the exchange rate flexibility, with a view to have a floating system de facto not de jure. The relative flexibility of the exchange-rate system resulted in a depreciation trend for the REER, fed by negative terms of trade shocks and by increased openness of the economy. The authorities continue lowering custom duties to comply with international commitments such as World Trade Organization, UE agreement, and Arab Maghreb Union free-trade agreements ...etc. and to stimulate trade across borders.

\subsection{The Cashin's (2002) Model}

After Edwards' model [6,8], we'll, in this section, apply the Cashin et al. (2002) model [2]. The REER is defined as a function of relative productivities between tradable and non-tradable sectors, as well as the terms of trade [14]:

$$
E P / P^{*}=f\left(a_{x} / a_{i}^{*}, a_{n}^{*} / a_{n}, p_{x}^{*} / p_{i}^{*}\right)
$$

where:

- $E P / P^{*}=$ the real exchange rate defined as the domestic price of the domestic basket of consumption goods relative to the price of the foreign basket of consumption goods expressed in foreign currency ;

- $a_{x} / a_{i}^{*}=$ productivity differential between exports and import (foreign) sectors or between domestic and foreign tradable sectors;

- $a_{n}^{*} / a_{n}=$ productivity differential between the foreign and domestic non-tradable sectors;

- $p_{x}^{*} / p_{i}^{*}=$ commodity terms of trade (or the price of the primary commodity with respect to the intermediate foreign good) measured in foreign prices.

The first two terms in equation (6) capture the Balassa-Samuelson effect ${ }^{*}$ which translates into a price increase in the non-tradable sector, which in turn, leads to an appreciation of the real exchange rate. The third term reflects the impact of the terms of trade. An increase in

\footnotetext{
${ }^{*}$ The well-known analysis of Balassa (1964) and Samuelson (1964) provides an appealing explanation of the long-run behaviour of the real exchange rate in terms of the productivity performance of traded relative to non-traded goods. Basically, the argument is that as the productivity of traded goods rises relative to that of non-traded goods, there will be a tendency for the rate exchange rate to appreciate. Balassa-Samuelson effects are generally thought to be the key source of observed crosssectional differences in real exchange rates (the same currency prices of comparable commodity baskets) between countries at different levels of income per capita.
} 
export prices leads to higher wages, and translates into an increase in non-tradable goods prices as well.

\subsubsection{Data Source and Variables Definition}

The theoretical formula which defines our model is represented by the following equation:

$$
\text { LREER }=\beta_{0}+\beta_{1} L B S E+\beta_{2} L R O I L+\varepsilon
$$

where:

- LREER= the real effective exchange rate: in logarithmic terms $(2010=100)$.

- $\mathrm{LBSE}=$ Real GDP per capita relative to trading partners.

- $\quad$ LROIL = Real price of oil. Since Algeria's exports mainly rely on its oil exports (Hydrocarbons still topped the list of Algerian exports and account for more than 95 percent of total exports). This is a proxy for the commodity terms of $\operatorname{trade}\left(P^{*}{ }_{x} / P^{*}{ }_{i}\right)$. Real price of oil using World Bank data (Crude oil, Brent, $\$ /$ bbl. 2010=100), in logarithmic terms.

\subsubsection{Unit Root Tests}

The dataset consists of annual data from 1980 to 2015 . The ADF [5] and Phillips -Perron tests [17], indicate that the non-stationary hypothesis cannot be rejected in level for all three variables. However, for the first difference of the same variables The Phillips -Perron test indicate that the hypothesis of non-stationary is rejected at 1 percent confidence level, suggesting that these variables (REER, BSE and Roil) are integrated of order one I(1), (Table 4).

\subsubsection{Cointegration Tests}

Cointegration tests confirm the existence of one cointegration relationship between the REER, real oil prices, and Algeria's productivity differential relative to its trading partners (Balassa-Samuelson effect), as referred in Table 5 and Table 6.

\subsubsection{Finding and Discussion}

The estimated long-run real exchange rate equilibrium equation takes the following form:

LREER $=0.85361$ LROIL -1.2664 LBSE $? 11.1132$

$$
\begin{array}{ll}
(0.05158) & (0.05559) \\
{[16.5497]} & {[-22.7829]}
\end{array}
$$

- An increase in real oil prices of 1 percent is associated with an appreciation of the REER of about 0.85 percent.

- An increase in BSE (real GDP per capita relative to trading partner countries) of 1 percent is associated with a depreciation of the REER of about 1.26

\begin{tabular}{|c|c|c|c|c|c|}
\hline & \multirow{2}{*}{ Variables } & \multicolumn{2}{|c|}{ Level } & \multicolumn{2}{|c|}{ First Difference } \\
\hline & & $\mathrm{t}-\mathrm{ADF}$ & t-PP & $\mathrm{t}-\mathrm{ADF}$ & t-PP \\
\hline \multirow{2}{*}{ LREER } & \multirow{2}{*}{ Intercept Trend and Intercept } & -1.422824 & -1.050156 & $-4.337642 * * *$ & $-4.337642 * * *$ \\
\hline & & -1.109913 & -1.411798 & $-4.258721 * *$ & $-4.287875 * * *$ \\
\hline \multirow{2}{*}{ LROIL } & \multirow{2}{*}{ Intercept Trend and Intercept } & -1.280134 & -1.314870 & $-5.345141 * * *$ & $-5.344472 * * *$ \\
\hline & & -2.054737 & -2.046248 & $-5.344635^{* * *}$ & $-5.341975 * * *$ \\
\hline \multirow{2}{*}{ LBSE } & \multirow{2}{*}{ Intercept Trend and Intercept } & $-2.713712 *$ & -1.641021 & -1.452776 & $-4.416052 * * *$ \\
\hline & & -0.884321 & -1.090010 & -1.620210 & $-4.565153 * * *$ \\
\hline
\end{tabular}
percent. It is factor augmenting that dominates.

Table 4. ADF and PP Unit Root Tests

Notes: Variables are as defined in the text. $* * *$ and $* * *$ denote rejection at $10 \%, 5 \%$ and $1 \%$ critical values.

Table 5. Trace test for cointegration rank

\begin{tabular}{|c|c|c|c|}
\hline & Eigenvalue & Trace Statistic & $\begin{array}{c}0.05 \\
\text { Pritical Value }\end{array}$ \\
\hline None $^{*}$ & 0.504381 & 30.54092 & 29.79707 \\
\hline At most 1 & 0.138349 & 6.674701 & 15.49471 \\
\hline At most 2 & 0.046304 & 1.611934 & 0.0410 \\
\hline
\end{tabular}

Trace test indicates 1 cointegrating eqn(s) at the 0.05 level

* denotes rejection of the hypothesis at the 0.05 level

**MacKinnon-Haug-Michelis (1999) p-values

Table 6. Max-Eigen statistics for cointegration rank

\begin{tabular}{|c|c|c|c|}
\hline & Eigenvalue & Max-Eigen Statistic & $\begin{array}{c}0.05 \\
\text { Pritical Value }\end{array}$ \\
\hline None $^{*}$ & 0.504381 & 23.86622 & 21.13162 \\
\hline At most 1 & 0.138349 & 5.062767 & 14.26460 \\
\hline At most 2 & 0.046304 & 1.611934 & 0.0201 \\
\hline
\end{tabular}

Max-eigenvalue test indicates 1 cointegrating eqn(s) at the 0.05 level

* denotes rejection of the hypothesis at the 0.05 level

**MacKinnon-Haug-Michelis (1999) p-values. 


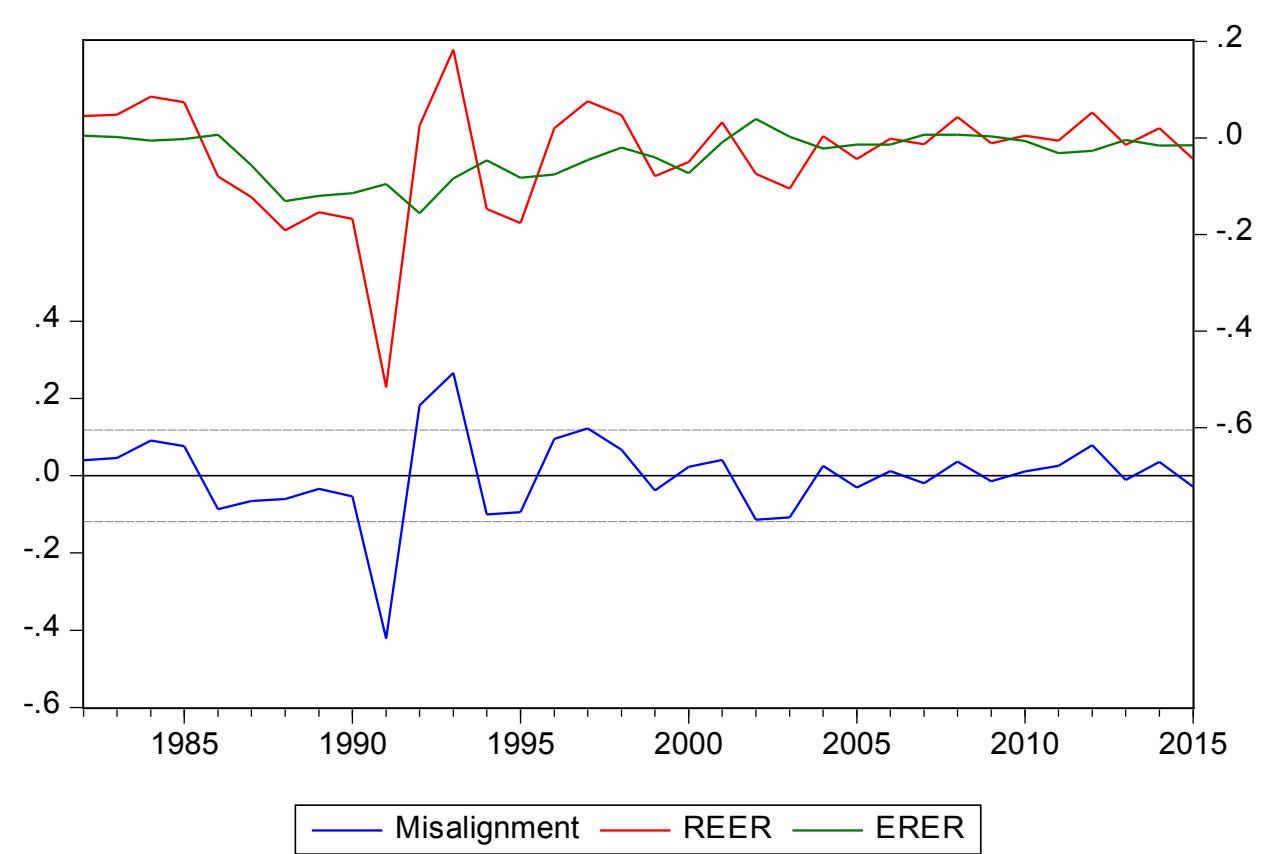

Figure 2. Actual RER, Equilibrium RER and Degree of Misalignment

Figure 2 shows the same results as Figure 1, where there are three under-valuate episodes of DZD: (19861991, 1994-1995 and 2002-2003), and three episodes of DZD's overvaluation (1982-1985, 1992-1993 and 19962001 except 1999). The Actual REER appears to have been close to its estimated equilibrium since 2004 until 2015. Figure 2 shows also that the variation of Algerian misalignment was very large, between 1991 (-42\%) and $1993(+27 \%)$.

\section{Conclusion}

The empirical results of this paper show that our macroeconomic policy variables such as terms of trade, trade openness, differential productivity with those trading partners (Balassa-Samuelson effect), real price of oil and government consumption (spending), play significant role in determining the equilibrium Algeria's REER. The results also reveal that during the period under study, the Algerian economy suffered from RER misalignment, particularly overvaluation.

We used Johansen Cointegration approach to estimate the equilibrium real effective exchange rate for Algerian dinar, based on various macroeconomic fundamentals.

According to the Edwards' (1987) Model this research has identified three Algerian dinar's under-valuate episodes (1986-1991 period, 1994-1995 period and 2002-2003 period) and three episodes of overvaluation ones (19821985 period, 1992-1993 period and 1996-2001 period except 1999) and the Actual REER appears to have been close to its estimated equilibrium since 2004 until 2015. According to the Cashin's (2002) model this research has identified the same results as Edwards' model.

Algeria's dependence on a commodity exports (more than 95 percent of hydrocarbon exports), combined with observed volatility of the world's commodity prices suggests that the government's efforts to diversify the country's export base will be important to maintain competitiveness. On the other hand, policy makers should pay considerable attention to policy factors that misalign the RER in Algeria, such as trade openness, taxes and government expenditure. Thus, tightened fiscal and monetary policies, and adequate tariff policy should be implemented to maintain the exchange rate at a sustainable stable level.

\section{References}

[1] Balassa, B. "The purchasing-Power Parity Doctrine: a Reappraisa", Journal of Political Economy, 72, 584-96, 1964.

[2] Cashin, P. L. Céspedes, and R. Sahay, Keynes, Cocoa, and Copper: In Search of Commodity Currency, International Monetary Fund Working paper, 02/223, Washington, 2002.

[3] Choudhri, E.U. and M.S. Khan. Real Exchange Rate in Developing Countries: Are Balassa-Samuelson Effects Present?, International Monetary Fund Working paper, 04/188, Washington, 2004.

[4] Clark, P. B. \& R. MacDonald, Exchange Rate and Economic Fundamentals: A Methodological Comparison of BEERs and FEERs, International Monetary Fund Working paper, 98/67, Washington, March 1998.

[5] Dickey, D. and W. Fuller. "Likelihood Ratio Statistics for Autoregressive Time Series with a Unit Root", Econometrica, 49, 1981.

[6] Edwards, S, Exchange Rate Misalignment in Developing Countries, Discussion Paper $\mathrm{N}^{\circ} 442$, University of California, Los Angeles and National Bureau of Economic Research, 1987.

[7] Edwards, S, Real and Monetary Determinants of Real Exchange Rate Behaviour: Theory and Evidence from Developing Countries, NBER Working Paper $N^{\circ} 2721$, Nation Bureau of Economic Research, 1988.

[8] Edwards, S, Real Exchange Rates, Devaluation and Adjustment: Exchange Rate Policies in Developing countries, MIT Press, Massachusetts, USA, 1989 ,

[9] Edwards, S, Real Exchange Rate in the Developing Countries: Concepts and Measurement, NBER Working Paper $\mathrm{N}^{\circ} 2950$, Nation Bureau of Economic Research, Massachusetts, 1989,

[10] Elbadwi, I., Estimating Long-run Equilibrium Real Exchange Rate, in Estimating Equilibrium Exchange Rate, edited by J. Williamson, Institute for International Economics, Washington, 1994.

[11] Engle, R.F and C. Granger. "Co-integration and Error Correction: Representation, Estimation and Testing," Econometrica, 55, 251-76, 1987,

[12] Frikha, W. and N. Hachicha. "Real Exchange Rate Misalignment and Economic Growth. Case of Seven MENA Countries", IJE, $7(2), 147-60,2013$, 
[13] Hiri, A., "The Real Effective Exchange Rate Misalignment Application of Behavioural Equilibrium Exchange Rate BEER to Algeria 1980-2009", International Journal of Economics, Finance and Management Sciences, 2(5), 277-284, 2014,

[14] Koranchelian, T, The Equilibrium Real Exchange Rate in a Commodity Exporting Country: Algeria's Experience, IMF Working Paper, 05/135, Washington, USA, 2005,

[15] Madouni, M.. "Real Exchange Rate Misalignment in Algeria", International Journal of Arts and Commerce, 3(5), 37-50, 2014.

[16] Meese, R. A. \& Rogoff, K. "Empirical exchange rate models of the seventies, do they fit out of sample", Journal of International Economics, 14, 1983.
[17] Phillips, P.C.B. and P. Perron. "Testing for a Unit Root in Times Series Regression", Biometrika, 75, 335-46, 1988

[18] Samuelson, P, "Theoretical Notes and Trade Problems", Review of Economics and Statistics, 46, 145-54, 1964

[19] Stein, J.L. "The Natural Real Exchange Rate of the US dollar and determinants of capital flows", in Estimating Equilibrium Exchange Rate, ed. J. Williamson, Institute of International Economics, Washington D.C., 1994.

[20] Williamson, J. “Estimates of FEER's”, in Estimating Equilibrium Exchange Rate, ed. J. Williamson, Institute of International Economics, Washington D.C., 177-243, 1994. 